CLINICAL STUDY

\title{
Autosomal recessive familial neurohypophyseal diabetes insipidus: onset in early infancy
}

\author{
Abdulsalam Abu Libdeh, Floris Levy-Khademi, Maha Abdulhadi-Atwan, Emily Bosin ${ }^{1}$, Mira Korner ${ }^{2}$, \\ Perrin C White ${ }^{3}$ and David H Zangen \\ Division of Pediatric Endocrinology, Department of Pediatrics, Hadassah Hebrew University Medical Center, PO Box 24035, 91240 Jerusalem, Israel, \\ ${ }^{1}$ Laboratory of Endocrinology, Soroka University Medical Center, Beer Sheva, 84101 Israel, ${ }^{2}$ Center for Genomic Technologies, Hebrew University, \\ 91904 Jerusalem, Israel and ${ }^{3}$ Division of Pediatric Endocrinology, University of Texas Southwestern Medical Center, Dallas, 75390 Texas, USA \\ (Correspondence should be addressed to D H Zangen; Email: zangend@hadassah.org.il)
}

\begin{abstract}
Background: Familial neurohypophyseal diabetes insipidus (FNDI), usually an autosomal dominant disorder, is caused by mutations in the arginine vasopressin (AVP)-neurophysin II preprohormone leading to aberrant preprohormone processing and gradual destruction of AVP-secreting cells. Patients typically present between 1 and 6 years of age with polyuria and polydipsia.

Objective: Clinical, biochemical, and genetic studies of three new cases of autosomal recessive FNDI presenting in early infancy.

Patients: Three Palestinian cousins presented with failure to thrive, vomiting, irritability, and fever. The parents were asymptomatic. Patients developed hypernatremia (154-163 mmol/l) and serum hyperosmolality ( $>320 \mathrm{mOsm} / \mathrm{kg}$ ), while urine osmolality remained between 73 and $229 \mathrm{mOsm} / \mathrm{kg}$. Plasma AVP levels were low, and the posterior pituitary bright spot was absent on magnetic resonance imaging (MRI). All patients responded to desmopressin.

Results: Patients were homozygous and parents were heterozygous for microsatellite markers flanking the AVP gene. All patients were homozygous for the P26L (proline to leucine) substitution affecting mature AVP. A founder effect with the single original kindred carrying the P26L mutation was confirmed by microsatellite analysis, but patients in that family presented only at 2 years of age. In microsatellite analysis, the new kindred patients were not homozygous and did not share a single allele at the aquaporin 2 and vasopressin receptor- 2 genes locuses.

Conclusion: This is the first description of autosomal recessive FNDI presenting in the neonatal period. The unusual early clinical and radiological (MRI) presentation argues against gradual destruction of AVP-secreting neurons as the pathophysiological mechanism. Factors beside allelism of AVP-related genes must influence the age of FNDI presentation given the founder effect demonstrated for the P26L mutation.
\end{abstract}

European Journal of Endocrinology 162 221-226

\section{Introduction}

Neurohypophyseal or central diabetes insipidus is a disorder of water conservation resulting from a deficiency of arginine vasopressin (AVP). It is usually caused by tumors, infection, or trauma (1). Familial neurohypophyseal diabetes insipidus (FNDI) is a rare disorder accounting for only $1 \%$ of central diabetes insipidus patients (2); it is caused by mutations in the AVP gene on chromosome 20 (3), usually inherited in an autosomal dominant pattern (4). FNDI typically presents between the ages of 1 and 6 years with polyuria and polydipsia (5-7), and is radiologically characterized by the loss of the posterior pituitary bright spot on T1 magnetic resonance imaging (MRI), indicating dysfunction of the neurohypophysis (8-11).
AVP is synthesized as a preprohormone by specialized hypothalamic neurons with long extensions projecting through the diaphragma sellae to form the neurohypophysis (12). Biosynthesis of AVP starts with tightly regulated transcription of the AVP gene (13), continues with regulated translation and enzymatic cleavage of the AVP-neurophysin II (AVP-NPII) prohormone (14-17), and ends with active AVP secretion into the circulation upon an appropriate stimulus (i.e. hyperosmolality and hypovolemia).

The first of the three exons of the AVP gene (14-15) encodes a signal peptide, AVP, and the amino terminus of NPII; the second encodes the NPII central region, and the third gives rise to NPII's carboxy terminus and to a glycoprotein (16). Since the first reported AVP-NPII 
mutation (18), 56 others have been described, mostly in the signal peptide or the NPII moiety of the preprohormone. These are presumed to interfere with preprohormone processing leading to neuronal damage and gradual destruction of AVP-secreting cells (19). Only one autosomal recessive mutation causing FNDI (P26L, affecting the seventh of nine amino acids of the mature AVP hormone) has been previously described. The three affected children in that kindred all developed polyuria between 1.5 and 2 years of age (20).

The present study describes clinical and molecular studies of three cases of autosomal recessive FNDI in newly ascertained kindred (the second described worldwide) (20), but with an unusual age of presentation, in very early infancy. This distinct presentation strongly suggests the existence of genetic or environmental factors that can modify the phenotype of FNDI.

\section{Methods}

\section{AVP assay}

Blood samples were collected into ice-chilled tubes following discontinuation of desmopressin treatment for at least $36 \mathrm{~h}$. Plasma AVP levels were measured by RIA with a preceding extraction procedure as described by Glick et al. (21).

\section{Microsatellite markers}

Genomic DNA was extracted from whole blood samples from patients $1-3$ and their parents, as well as from one patient from the previously described kindred, using the MagNA Pure Compact System and kit (Roche Diagnostics $\mathrm{GmbH}$ ). Patients were genotyped for microsatellite markers using fluorescence dye-labeled forward primer and unlabeled reverse primer and PCR conditions as described in the ABI manual (ABI, Applied Biosystems, Foster City, CA, USA). The microsatellite markers analyzed were D20S906, D20S842, and D20S193 flanking the AVP gene; D12S85 and D12S368 flanking the aquaporin 2 (AQP2) gene, and DXS8069 and DXS1073 flanking the vasopressin receptor (V2R) gene. Fluorescently labeled PCR products were pooled, and 1-2 $\mu \mathrm{l}$ were sampled into $9 \mu \mathrm{l}$ loading buffer (formamide with GENESCAN 400HD (ROX) size standard, Applied Biosystems). PCR products were analyzed with the 3700 Automated DNA Analyzer using GENESCAN and GENOTYPER software (Applied Biosystems).

\section{Sequencing of the AVP gene}

Genomic DNA was amplified using a PTC 225 DNA Engine (MJ Research Hercules, CA, USA). Fifty nanograms of DNA sample were added to $10 \mathrm{pmol}$ of each primer, $1.5 \mathrm{mM} \mathrm{MgCl}_{2}, 0.2 \mathrm{mM}$ dNTP's, $1 \times$ PCR Gold buffer (15 mM Tris-HCl, pH 8.0, $50 \mathrm{mM} \mathrm{KCl}$ ), and 0.4 unit of AmpliTaq Gold DNA polymerase (both from ABI) in a total volume of $25 \mu \mathrm{l}$. PCR conditions included initial 12-min denaturation at $95^{\circ} \mathrm{C}, 37$ cycles of $1 \mathrm{~min}$ at $92{ }^{\circ} \mathrm{C}, 1 \mathrm{~min}$ at $55^{\circ} \mathrm{C}$ and $1 \mathrm{~min}$ at $72{ }^{\circ} \mathrm{C}, 10 \mathrm{~min}$ at $72{ }^{\circ} \mathrm{C}$. Primers for amplification and sequencing of the AVP gene were exon 1: F: gctatggctgccctgagatggcccacagtg, R: tggcggccgcgtctcgcctccacgggaaca; exon 2: F: cgeccccccccaggeccgeccecgecgcgc, R: tcgetgegttcccctccaacccetcgactc; exon 3: F: cctctctcccttccetcttcccgccagag, R: cccaggcgeccgtgctcacacgtcctcccg.

After PCR cleanup (incubation of $5 \mu \mathrm{l}$ PCR reaction with $2 \mu \mathrm{l} \mathrm{SAP/Exo} \mathrm{(USB)} \mathrm{for} 1 \mathrm{~h}$ at $37^{\circ} \mathrm{C}$ followed by $15 \mathrm{~min}$ at $80^{\circ} \mathrm{C}$ ), automated DNA sequencing was performed using Big-Dye terminator cycle sequencing chemistry on the ABI PRISM 3700 DNA Analyzer.
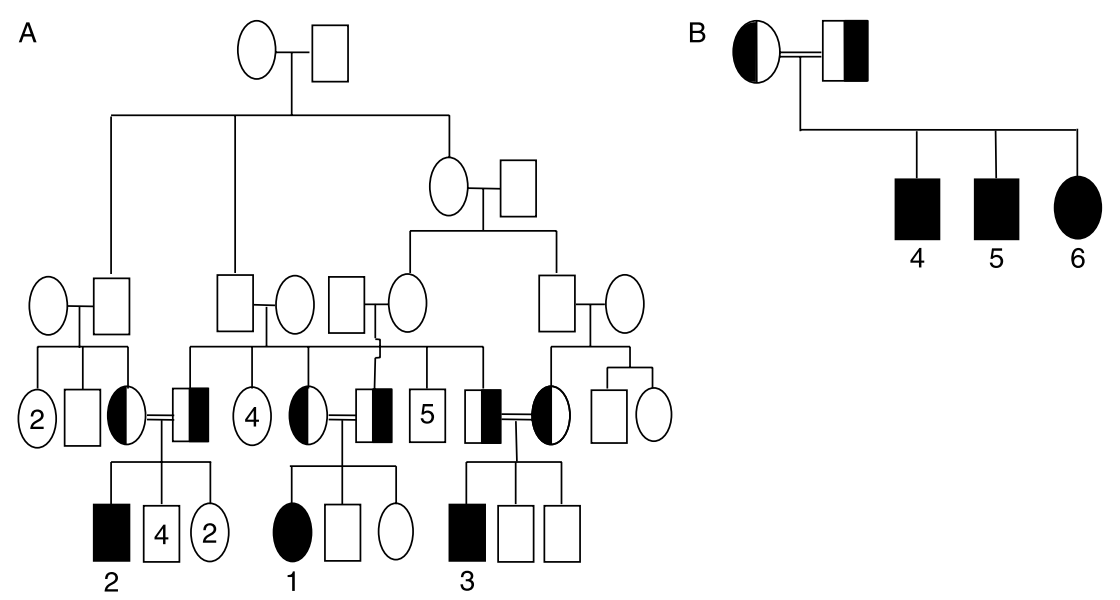

Figure 1 Pedigrees of the affected families; (A) new and (B) previously reported (Texas). Affected homozygous cases are indicated by filled squares or circle and numbered. Half-filled squares or circles indicate heterozygotes. Numbers within the boxes indicate number of siblings not individually plotted in the pedigree. Consanguinity is indicated by double lines. 
Table 1 Clinical and laboratory characteristics of affected patients.

\begin{tabular}{|c|c|c|c|c|c|c|c|c|c|c|}
\hline & Sex & $\begin{array}{l}\text { Age of first } \\
\text { symptom } \\
\text { (years) }\end{array}$ & $\mathrm{Na}$ & $\begin{array}{l}\text { Osm } \\
\text { blood }\end{array}$ & $\begin{array}{l}\text { Osm } \\
\text { urine }\end{array}$ & $\begin{array}{c}\text { AVP } \\
(\mathrm{pg} / \mathrm{ml})\end{array}$ & MRI & $\begin{array}{c}\text { Current } \\
\text { age } \\
\text { (years) }\end{array}$ & $\begin{array}{l}\text { Height centile } \\
\text { (cm, percentile) }\end{array}$ & $\begin{array}{l}\text { Other clinical } \\
\text { manifestations }\end{array}$ \\
\hline Case 1 & $\mathrm{~F}$ & 0.1 & 158 & 320 & 229 & 0.77 & Absent bright spot & 8.75 & 129,25 & \\
\hline Case 2 & $\mathrm{M}$ & 0.1 & 159 & 283 & 73 & 0.75 & Absent bright spot & 7.5 & 125,50 & \\
\hline Case 3 & $\mathrm{M}$ & 0.1 & 154 & 315 & 189 & 2.77 & Absent bright spot & 5.2 & $110.4,50$ & \\
\hline Case $4^{a}$ & $\mathrm{M}$ & 4.25 & 149 & 312 & 67 & 6.8 & Absent bright spot & 18.9 & $185.5,91$ & $\begin{array}{l}\text { GH deficiency } \\
\text { secondary } \\
\text { hypogonadism }\end{array}$ \\
\hline Case $5^{a}$ & $M$ & 2 & 147 & 317 & 81 & 8.4 & Absent bright spot & 15.3 & $180.1,89$ & $\begin{array}{l}\text { GH deficiency } \\
\text { deafness }\end{array}$ \\
\hline Case $6^{a}$ & $\mathrm{~F}$ & 1.25 & 140 & 293 & 428 & 3.8 & Normal & 13.2 & $158.5,56$ & Deafness \\
\hline
\end{tabular}

Osm, osmolarity.

apart of the clinical data of cases $4-6$ is cited from Ref. (20).

Informed consent was obtained from study participants, and studies were approved by the Institutional Review Boards of Hadassah Hebrew University Medical Center and Southwestern Medical Center.

\section{Results}

\section{Clinical presentations and studies}

Three affected children, cousins in single extended Palestinian kindred (Fig. 1A, patients 1-3), were studied. Each presented with irritability, vomiting, diarrhea, failure to thrive, and intermittent fever developing gradually during the first few weeks of life.
Hypernatremia, high serum osmolality and inappropriately low urine osmolality and inappropriately low AVP levels $(0.77,0.75$, and $2.77 \mathrm{pg} / \mathrm{ml}$ respectively) were consistent with diabetes insipidus (Table 1). Anterior pituitary hormone levels were normal, but the posterior pituitary bright spot could not be visualized by MRI (performed at 2 months of age at normal serum osmolarity levels of $285-290 \mathrm{mOsm} / \mathrm{l}$ ) in any of the three patients. All responded well to desmopressin treatment and grew and developed normally. Patients 4-6 (Fig. 1B), from an unrelated Arab kindred described previously (20), presented later in childhood and had relatively high AVP levels. Desmopressin replacement was initiated only at 4.3 years for case $4,2.3$ years for case 5 , and 1.7 years for case 6 (Table 1 ). The mother and

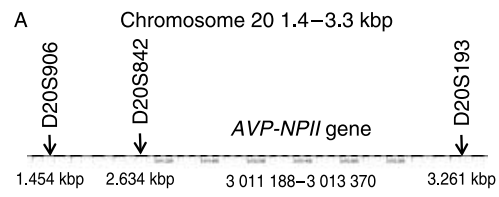

C
\begin{tabular}{|l|r|r|r|r|r|r|}
\hline \multicolumn{1}{|c|}{ AVP } & \multicolumn{2}{|c|}{ D20S906 } & \multicolumn{2}{c|}{ D20S842 } & \multicolumn{2}{c|}{ D20S193 } \\
\hline Case 1 & 236 & 236 & 165 & 165 & 140 & 140 \\
\hline Case 2 & 236 & 236 & 165 & 165 & 140 & 140 \\
\hline Case 3 & 236 & 236 & 165 & 165 & 140 & 140 \\
\hline Father & 236 & 240 & 165 & 169 & 140 & 150 \\
\hline Mother & 236 & 240 & 159 & 165 & 140 & 146 \\
\hline Brother & 236 & 240 & 159 & 169 & 146 & 150 \\
\hline \hline Case 4 & 236 & 236 & 165 & 165 & 140 & 140 \\
\hline
\end{tabular}
*Kindred 1B
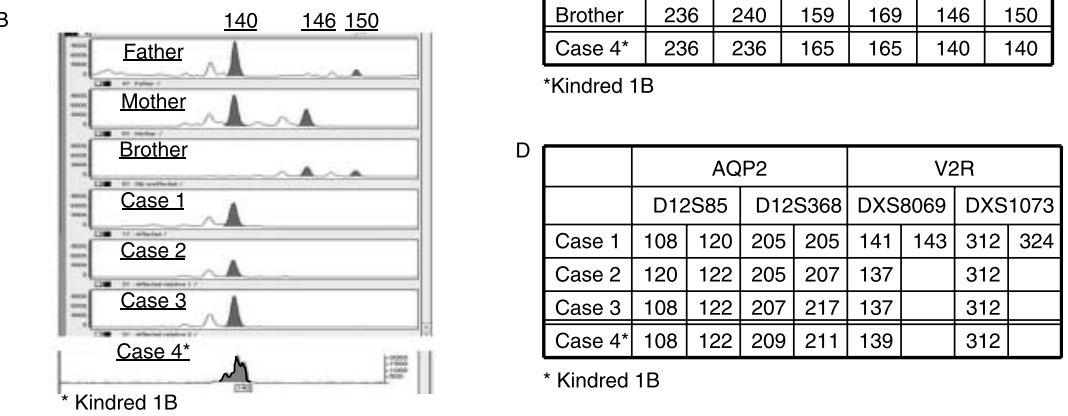

Figure 2 Linkage analysis of the AVP-NPII V2R and AQP2 genes. (A) Map of the AVP gene locus and its flanking regions on chromosome 20 indicating the positions of the microsatellite markers D20S906, D20S842, and D20S193 used for linkage analysis. (B) Example of a microsatellite marker study on cases 1-3 and family members of patient 2. Cases 1-3 are homozygous for short tandem repeats (STRs) length for the D20S193 marker; (one single gray peak at 140) compared to the parents and brother of case 2 who are heterozygous (two gray peaks). Case $4^{*}$ from kindred $B$ is also homozygous for this marker with the same length of 140 (suggesting a founder effect). (C) A table summarizing the results of the linkage analysis with the three microsatellite markers. Cases 1-3 are homozygous for short tandem repeats (STRs) lengths for all three markers flanking the AVP-NPII gene whereas the parents and a healthy brother (of case 2 shown as an example for the three families) are heterozygous. Case $4^{*}$ from the previously reported kindred (Fig. 1B) has the same genotype as cases 1-3. (D) Table summarizing the results of linkage analysis with microsatellite markers flanking the aquaporin 2 (AQP2) and V2 receptor (V2R) genes. None of patients 1-3 was homozygous at $A Q P 2$, and there was no common shared allele at the AQP2 or V2R loci. 
cases 5 and 6 also had sensorineural deafness. MRI studies revealed no bright spot in patients 4 and 5 , but in patient 6 the bright spot was still present at 2 years in spite of clinically apparent diabetes insipidus (DI). The growth rate of patients 4 and 5 was deteriorated during adolescence and following diagnosis of $\mathrm{GH}$ deficiency by $\mathrm{GH}$ stimulation tests (peak secretion -0.27 and $3.0 \mathrm{ng} / \mathrm{ml}$ respectively) replacement therapy was initiated with good response. Patient 4 was also diagnosed with hypogonadotrophic hypogonadism during adolescence. The consanguineous parents of the affected children in each kindred were unaffected with normal osmolarity and AVP levels, suggesting autosomal recessive inheritance.

\section{Molecular studies}

All three new cases had identical homozygous genotypes for the D20S906, D20S842, and D20S193 microsatellite markers flanking the AVP gene on chromosome 20 (Fig. 2B and C), whereas the parents were heterozygous; this finding strongly suggested that a mutated $A V P$ gene caused the DI in our patients.

Sequencing of the AVP gene revealed that all three patients were homozygous for a missense mutation at nucleotide 301 (C to T) (Fig. 3), predicting a substitution of proline to leucine (P26L) at the seventh amino acid residue of mature AVP. The parents were heterozygous for this mutation. No other mutations were found in the $A V P$ gene.

The finding of the same mutation in patients $1-3$ in Israel and in the previously reported kindred in Texas (20), despite no known relation between the two Palestinian families, led us to look for a founder effect. The oldest patient in the previous kindred indeed had identical alleles in the microsatellite markers flanking the AVP gene as patients 1-3, suggesting common inheritance (Fig. 2B and C).

To identify other mutated proteins contributing to the early clinical presentation of DI in patients 1-3, we looked for common inheritance of alleles for genes encoding two proteins mediating the effects of AVP in the kidney, the AVP type 2 receptor (V2R), and the AQP2 water channel. No patient in our kindred was homozygous for microsatellite markers flanking the AQP2 gene on chromosome 12; moreover, these three cousins did not share a common allele at this locus

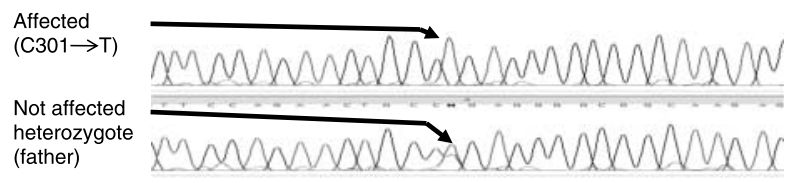

Figure 3 Mutation in the AVP gene. Representative sequencing results of case 2 and his father showing a homozygous missense mutation at nucleotide 301 (CCG-CTG) for the patient and heterozygosity for the father predicting a proline to leucine substitution at position 26 of the AVP-NPII prohormone.
(Fig. 2D). Patient 1, a female, was not homozygous for microsatellite markers flanking the $V 2 R$ gene on chromosome $\mathrm{X}$, nor did the three patients share a common allele at this locus.

\section{Discussion}

FNDI is a rare disease caused by mutations in the AVP gene, most of which are located in the region encoding the NPII moiety. We describe the fifth reported kindred worldwide with a mutation affecting mature AVP, and the second with autosomal recessive mode of inheritance (20). All affected infants in our kindred were homozygous for a mutation predicting a substitution of leucine for proline at position 7 of AVP itself (P26L in the AVP-NPII preprohormone).

The unique location of this mutation may be responsible for the unusual recessive mode of inheritance. The presumed pathophysiological mechanism in most cases of FNDI involves a defective tetrameric threedimensional structure of the prohormone and aberrant intracellular prohormone processing (22-24). Eventually, this results in cellular damage from abnormal accumulation of unprocessed AVP-NPII tetramers. The dominant negative effect caused by even one out of four aberrant AVP-NPII subunits in a tetramer may account for the typical dominant mode of inheritance (25-27). The location of the P26L mutation, however, has not been considered crucial for folding or processing of the AVP preprohormone $(22,28,29)$. Thus, the P26L prohormone, unlike mutations associated with autosomal dominant FNDI, is apparently folded, dimerized, and transported with little effect on cellular integrity in the heterozygous state. Although the processing and the actual secretion pattern of the mutant AVP in neuroendocrine cell lines (e.g. Neuro 2A) has not been investigated yet, affected patients are able to secrete mutant AVP. This mutated hormone has a 30-fold decrease in binding to the $\mathrm{V} 2$ receptor and a tenfold decrease in ability to stimulate adenylate cyclase (20). Therefore, in the homozygous state, it was thought that the dramatically increased levels of AVP secretion required to maintain antidiuresis could eventually exhaust vasopressinergic neurons, leading to their death. Yet, in the newly ascertained kindred, all patients described here developed DI within weeks of birth, and their AVP levels were not elevated. The unequivocal absence of the bright spot in T1-weighted MRI images in the neonatal period of these patients may suggest prenatal or neonatal neuronal loss or complete failure to synthesize, accumulate, or maintain stores of mutant AVP-NPII prohormone in neurosecretory granules. This contrasts with the persistent bright spot at almost 2 years of age in patient 6 from the original family.

Why would the three patients reported here present so much earlier than patients in the previously reported kindred (1.5-5 years) carrying the same mutation? 
In spite of the known difficulty to accurately determine the exact age of the clinical presentation of DI especially in young patients, the difference in the time of presentation between the two families is major and should be addressed. One explanation could be a second mutation in our kindred, further interfering with AVP function, and decreasing the mutant AVP secretion capacity, but no such mutation was detected by sequencing all three exons of the AVP gene. Moreover, the affected patients in both kindreds share the same microsatellite alleles flanking the AVP gene locus, consistent with a founder effect.

The remaining possibilities include either epistasis with other genes or environmental stressors in the Palestinian family, compared with the first reported family, which lives in Texas. The lack of alleles in common for downstream proteins of the antidiuresis signaling pathway in the kidney (V2R or AQP2) did not support the involvement of these classical proteins in the pathogenesis of DI in this kindred. Regarding environmental stressors, the new Palestinian kindred comes from a middle class socioeconomic status without shortage in either food supply or housing conditions. The climate is not that different between the two countries, and the three cousins were born in different seasons of the year with no significant variability in the time of clinical presentation between them.

It is also difficult to relate the $\mathrm{GH}$ deficiency developing during adolescence in patients 4 and 5 to their FNDI. Although growth retardation has been reported in FNDI (30), our cases were adequately treated by desmopressin and clinically well for years prior to their growth retardation. The anterior and posterior pituitaries are anatomically and functionally distinct structures, and it is difficult to see how cell death affecting neuronal projections into the posterior pituitary could affect the anterior pituitary by triggering, for example, an inflammatory process. Finally, the lack of any other deficiencies in cases 1-3 and 6 (or in typical cases of autosomal dominant FNDI) makes such a local inflammatory process an unlikely pathophysiological explanation for anterior pituitary deficits.

In conclusion, FNDI can present in the neonatal period. A founder effect was demonstrated for the two kindreds with the $\mathrm{P} 26 \mathrm{~L}$ autosomal recessive mutation in the AVP moiety of the AVP-NPII gene. The early clinical presentation challenges the classical pathophysiological concept that a gradual apoptosis of neurons secreting AVP-NPII in the hypothalamus is responsible for FNDI. Additional factors modulating AVP synthesis, processing, storage, and/or action must be postulated given the discrepant clinical presentations in the two kindreds carrying the P26L mutation.

\section{Declaration of interest}

There is no conflict of interest that could be perceived as prejudicing the impartiality of the research reported.

\section{Funding}

This research did not receive any specific grant from any funding agency in the public, commercial, or not-for-profit sector.

\section{References}

1 Baylis PH \& Robertson GL. Vasopressin function in familial cranial diabetes insipidus. Postgraduate Medical Journal 198157 36-40.

2 Kaplowitz PB, D'Ercole AJ \& Robertson GL. Radioimmunoassay of vasopressin in familial central diabetes insipidus. Journal of Pediatrics 1982100 76-81.

3 Krawczak M, Ball EV, Fenton I, Stenson PD, Abeysinghe S, Thomas N \& Cooper DN. Human gene mutation database - a biomedical information and research resources. Human Mutation 200015 45-51.

4 Robertson GL. Diabetes insipidus. Endocrinology and Metabolism Clinics of North America $1995 \mathbf{2 4}$ 549-572.

5 McLeod JF, Kovacs L, Gaskill MB, Rittig S, Bradley GS \& Robertson GL. Familial neurohypophyseal diabetes insipidus associated with a single peptide mutation. Journal of Clinical Endocrinology and Metabolism 199377 599A-599G.

6 Mahoney CP, Weinberger E, Bryant C, Ito M, Jameson JL \& Ito M. Effects of aging on vasopressin production in a kindred with autosomal dominant neurohypophyseal diabetes insipidus due to the DeltaE47 neurophysin mutation. Journal of Clinical Endocrinology and Metabolism 200287 870-876.

7 Elias PC, Elias LL, Torres N, Moreira AC, Antunes-Rodrigues J \& Castro M. Progressive decline of vasopressin secretion in familial autosomal dominant neurohypophyseal diabetes insipidus presenting a novel mutation in the vasopressin-neurophysin II gene. Clinical Endocrinology 200359 511-518.

8 Miyamoto S, Sasaki N \& Tanabe Y. Magnetic resonance imaging in familial central diabetes insipidus. Neuroradiology 199133 272-273.

9 Fujisawa I, Nishimura K, Asato R, Togashi K, Itoh K, Noma S, Kawamura Y, Sago T, Minami S \& Nakano Y. Posterior lobe of the pituitary in diabetes insipidus: MR findings. Journal of Computer Assisted Tomography 198711 221-225.

10 Maghnie M, Sommaruga MG, Beluffi G \& Severi F. Role of MR imaging in the evaluation of the functional status of the posterior pituitary gland: the view of a pediatric endocrinologist. American Journal of Neuroradiology 199314 1443-1445.

11 Maghnie M, Villa A, Arico M, Larizza D, Pezzotta S, Beluffi G, Genovese E \& Severi F. Correlation between magnetic resonance imaging of posterior pituitary and neurohypophyseal function in children with diabetes insipidus. Journal of Clinical Endocrinology and Metabolism 1992 74 795-800.

12 Gainer H, Yamashita M, Fields RL, House SB \& Rusnak M. The magnocellular neuronal phenotype: cell-specific gene expression in the hypothalamo-neurohypophyseal system. Progress in Brain Research $20021391-14$.

13 Murphy D \& Wells S. In vivo gene transfer studies on the regulation and function of the vasopressin and oxytocin genes. Journal of Neuroendocrinology 200315 109-125.

14 Repaske DR, Phillips JA, Kirby LT, Tze WJ, D’Ercole AJ \& Battey J. Molecular analysis of autosomal dominant neurohypophyseal diabetes insipidus. Journal of Clinical Endocrinology and Metabolism $199070752-757$.

15 Riddel DC, Mallonee R, Phillips JA, Parks JS, Sexton LA \& Hamerton JL. Chromosomal assignment of human sequences encoding vasopressin-neurophysin II and growth hormone releasing factor. Somatic Cell and Molecular Genetics 198511 189-195.

16 Sausville E, Carney D \& Battey J. The human vasopressin gene is linked to the oxytocin gene and is selectively expressed in a cultured lung cancer cell line. Journal of Biological Chemistry 1985 $26010236-10241$. 
17 Acher R, Chauvet J \& Rouille Y. Dynamic processing of neuropeptides: sequential conformation shaping of neurohypophyseal preprohormones during intraneuronal secretory transport. Journal of Molecular Neuroscience 200218 223-228.

18 Ito M, Mori Y, Oiso V \& Saito H. A single base substitution in the coding region for neurophysin II associated with familial central diabetes insipidus. Journal of Clinical Investigation $1991 \mathbf{8 7}$ 725-728.

19 Christensen JH \& Rittig S. Familial neurohypophyseal diabetes insipidus - an update. Seminars in Nephrology 200626 209-223.

20 Willcutts MD, Felner E \& White PC. Autosomal recessive familial neurohypophyseal diabetes insipidus with continued secretion of mutant weakly active vasopressin. Human Molecular Genetics 1999 8 1303-1307.

21 Glick SM \& Kagan A. Vasopressin. In Methods of Hormone Radioimmunoassay, edn 2, pp 341-351. Eds BM Jaffe \& HR Behrman, New York: Academic Press, 1979.

22 Christensen JH, Siggaard C, Corydon TJ, Robertson GL, Gregersen N, Bolund L \& Rittig S. Differential cellular handling of defective arginine vasopressin (AVP) prohormones in cells expressing mutations of the AVP gene associated with autosomal dominant and recessive familial neurohypophyseal diabetes insipidus. Journal of Clinical Endocrinology and Metabolism 2004 89 4521-4531.

23 Wahlstrom JT, Fowler MJ, Nicholson WE \& Kovacs WJ. A novel mutation in the preprovasopressin gene identified in a kindred with autosomal dominant neurohypophyseal diabetes insipidus. Journal of Clinical Endocrinology and Metabolism $2004 \mathbf{8 9}$ 1963-1968.

24 Chitturi S, Harris M, Thomsett MJ, Bowling F, McGown I, Cowley D, Leong GM, Batch J \& Cotterill AM. Utility of AVP gene testing in familial neurohypophyseal diabetes insipidus. Clinical Endocrinology $200869926-930$.

25 Sitia R \& Braakman I. Quality control in the endoplasmic reticulum protein factory. Nature $2003 \mathbf{4 2 6} 891-894$.

26 Lee MC, Miller EA, Goldberg J, Orci L \& Schekman R. Bi-directional protein transport between the ER and Golgi. Annual Review of Cell and Development Biology 200420 87-123.

27 Lee YW, Lee KW, Ryu JW, Mok JO, Ki CS, Park HK, Kim YJ, Kim SJ, Byun DW, Suh KI, Yoo MH, Shin HB, Lee YK \& Kim CH. Mutation of Glu 78 of the AVP-NPII gene impairs neurophysin as a carrier protein for arginine vasopressin in a family with neurohypophyseal diabetes insipidus. Annals of Clinical and Laboratory Science 200838 12-14.

28 Rose JP, Wu CK, Hsiao CD, Breslow E \& Wang BC. Crystal structure of the neurophysin-oxytocin complex. Nature Structural and Molecular Biology 19963 163-169.

29 Wu CK, Hu B, Rose JP, Liu ZJ, Nguyen TL, Zheng C, Breslow E \& Wang BC. Structures of an unliganded neurophysin and its vasopressin complex: implications for binding and allosteric mechanisms. Protein Science 200110 1869-1880.

30 Nijenhuis M, van den Akker EL, Zalm R, Franken AA, Abbes AP, Engel H, de Wied D \& Burbach JPH. Familial neurohypophysial diabetes insipidus in a large Dutch kindred: effect of the onset of diabetes on growth in children and cell biological defects of the mutant vasopressin prohormone. Journal of Clinical Endocrinology and Metabolism 200186 3410-3420.

Received 11 October 2009

Accepted 3 November 2009 